\title{
Jurassic dinoflagellate cyst stratigraphy of Hold with Hope, North-East Greenland
}

\author{
Stefan Piasecki, Michael Larsen, Jens Therkelsen and Henrik Vosgerau
}

\begin{abstract}
Dinoflagellate cysts of the Middle-Upper Jurassic succession on northern Hold with Hope have been studied in order to establish a biostratigraphic framework and to date the succession. The Pelion Formation is characterised by abundant Chytroeisphaeridia byalina and Sentusidinium spp., with some Ctenidodinium thulium and Paragonyaulacysta retiphragmata in the lower part. Mendicodinium groenlandicum appears higher in the formation followed by Trichodinium scarburghense in the upper part. The succeeding Payer Dal Formation contains Scriniodinium crystallinum, Rigaudella aemula and Leptodinium subtile in the lower part and Dingodinium jurassicum and Prolixosphaeridium granulosum in the uppermost part. The Bernbjerg Formation contains abundant Sirmiodinium grossii and Gonyaulacysta jurassica. Adnatospahaeridium sp., Cribroperidinium granuligerum, Glossodinium cf. dimorphum and Scriniodinium irregulare appear in the lower part of the formation, followed by Avellodinium spp. in the highest part. The dinoflagellate cyst assemblages in the Pelion Formation indicate an Early-Late Callovian age $(C$. apertum - P. athleta Chronozones). This is supported by ammonites in the lower part of the formation, which refer to the C. apertum and P. koenigi Chronozones. A significant hiatus, from Late Callovian to Middle Oxfordian, is present between the Pelion Formation and the overlying Payer Dal Formation. The age of the Payer Dal Formation is Middle Oxfordian to earliest Late Oxfordian (C. tenuiserratum - A. glosense Chronozones). The Payer Dal Formation is conformably overlain by the Bernbjerg Formation of Late Oxfordian to possibly earliest Kimmeridgian age (A. glosense - P. baylei Chronozones). The A. glosense Chronozone is also documented by abundant ammonites in the lowermost part of the formation.
\end{abstract}

Keywords: ammonites, dinoflagellate cysts, Jurassic, North-East Greenland, stratigraphy

S.P., M.L., J.T.* \& H.V. ${ }^{\ddagger}$ Geological Survey of Denmark and Greenland, Øster Voldgade 10, DK-1350 Copenhagen K, Denmark. E-mail: sp@geus.dk

Present addresses: *Skude E Jacobsen, Noestvedvej 1, DK-4760 Vordingborg, Denmark.

${ }^{\ddagger}$ Roskilde Amt, Køgevej 80, DK-4000 Roskilde, Denmark.

The recognition of Middle-Upper Jurassic sediments on northern Hold with Hope added a missing link to the chain of Jurassic sedimentary exposures along the east coast of Greenland (Figs 1, 2; Stemmerik et al. 1997; Kelly et al. 1998; Larsen et al. 1997; Vosgerau et al. 2004, this volume). Sedimentological and biostratigraphical analysis of the succession formed the basis for correlation with lithostratigraphical units in Wollaston Forland and Jameson Land, and subdivision into the Pelion, Payer Dal and Bernbjerg Formations (Fig.
3). A new member of the Pelion Formation, the Spath Plateau Member, was erected (Vosgerau et al. 2004, this volume). Correlation was based on very few, poorly preserved Middle Jurassic ammonites in situ in the lower sandstone-dominated part of the succession, and more abundant Upper Jurassic ammonites of the Upper Oxfordian, the A. glosense Zone, in the mudstonedominated upper part of the succession. The content of dinoflagellate cysts was studied in order to improve the biostratigraphic dating of the succession, and to 


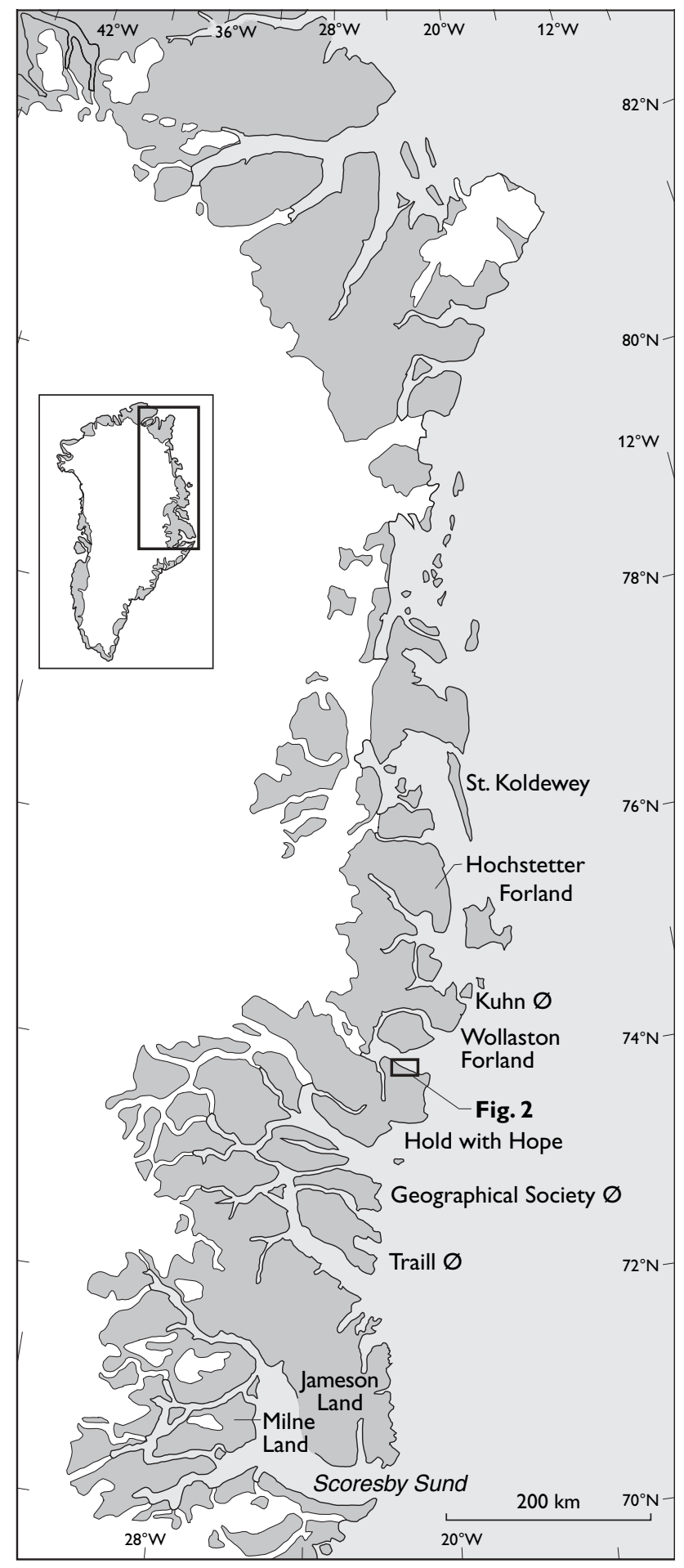

Fig. 1. Locality map of East Greenland and eastern North Greenland. The white region illustrates the permanent inland ice cap of Greenland, the grey areas are ice-free. Hold with Hope is located between $73^{\circ} \mathrm{N}$ and $74^{\circ} \mathrm{N}$. improve the knowledge of Jurassic dinoflagellate cysts in this region in general. The results reported here allow correlation with corresponding assemblages from Store Koldewey and Hochstetter Forland in the north and Jameson Land - Milne Land in the south (Fig. 1).

\section{Geological setting}

The Late Palaeozoic - Mesozoic extensional basin complex in East Greenland is approximately $700 \mathrm{~km}$ long in a north-south direction. Jurassic sediments are present and exposed from Jameson Land in the south to Store Koldewey in the north (Surlyk 1977). In the northern part of the rift system, e.g. the Wollaston Forland Basin, rifting was initiated in Middle Jurassic time, and marine Bajocian-Bathonian sandstones onlap Caledonian basement rocks or Permian carbonates (Vischer 1943; Surlyk 1978). Deposition took place on the hangingwall of W-SW-tilted fault blocks. Jurassic rifting culminated in the Volgian with strong rotational block faulting (Surlyk 1978). During this episode the wide original fault blocks, defining the Wollaston Forland Basin, were divided into smaller blocks (Vischer 1943; Surlyk 1978). A similar tectonic development may have occurred in the Geographical Society $\varnothing$ and Traill $\varnothing$ area towards the south (Donovan 1957; Price \& Whitham 1997). The Cretaceous period was generally characterised by subsidence controlled by thermal contraction (Surlyk et al. 1981; Price \& Whitham 1997). The East Greenland rift basin complex was uplifted during the Cenozoic.

Sediments of Jurassic age were first recognised on Hold with Hope by Stemmerik et al. (1997). They are limited to the north coast of Hold with Hope from Stensiö Plateau to Steensby Bjerg (Fig. 2), where they occur on the hangingwall of small fault blocks that dip mainly to the west and south-west. Bedding planes within the Triassic and Jurassic seem to be parallel, whereas the boundary with the overlying Cretaceous succession is an angular unconformity (Vosgerau et al. 2004, this volume). The thickness of the Jurassic succession varies significantly depending on its position on the hangingwall and the depth of Cretaceous erosion. The Jurassic succession includes shallow marine sandstones of the Pelion and Payer Dal Formations (Vardekløft Group), and offshore transition - lower shoreface heteroliths and offshore mudstones of the Bernbjerg Formation, Hall Bredning Group (Fig. 3). The Spath Plateau Member of the Pelion Formation was erected to accommodate sandy heteroliths and 


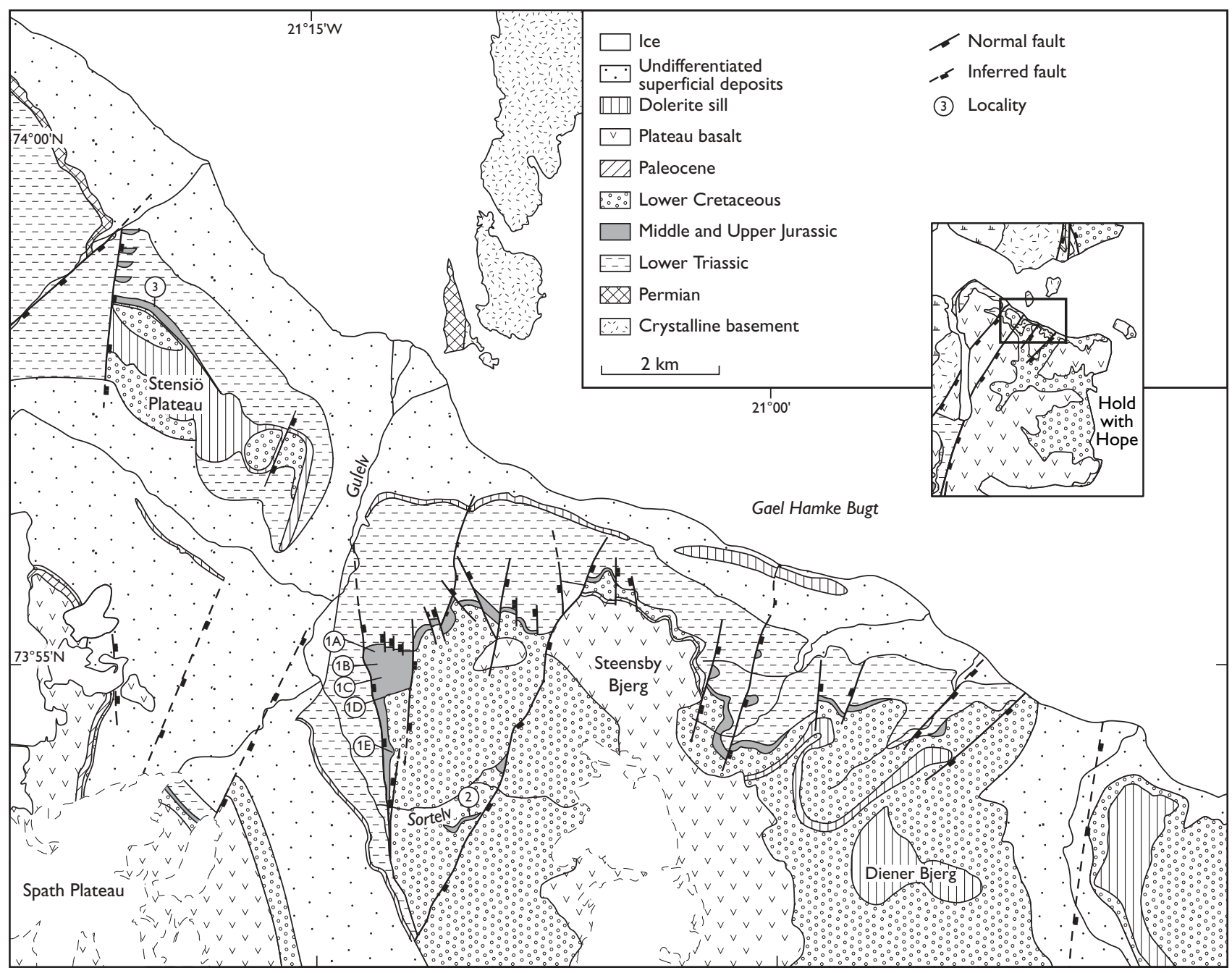

Fig. 2. Geological map of the northern Hold with Hope which illustrates the distribution of the studied Jurassic succession. Localities 1,2 and 3 are marked; the succession at Locality 1 has been compiled from a number of short laterally correlated sections (1A-1E).

offshore mudstones that contrast with the generally coarse-grained sandstone facies of the Pelion Formation (Vosgerau et al. 2004, this volume). The succession on Hold with Hope resembles the well-known Jurassic succession in the Wollaston Forland and Jameson Land Basins towards the north and south. The Middle Jurassic Pelion Formation is $c .190 \mathrm{~m}$ thick, the Upper Jurassic Payer Dal Formation is $50-80 \mathrm{~m}$ thick and the Bernbjerg Formation is estimated to be $c .130$ $\mathrm{m}$ thick (Fig. 4; Vosgerau et al. 2004, this volume).

\section{Samples and methods}

The dinoflagellate cysts have been studied in three sections (Fig. 4), in combination with a number of geographically and stratigraphically scattered samples on northern Hold with Hope. The main area of exposure is located on the northern and western slopes of Steensby Bjerg towards Gael Hamke Bugt and along the Gulelv river (Fig. 2, Locality 1). Samples from a number of short, vertical sections are combined into a composite section representing the entire succession (Fig. 2, Locality 1, sections A-E). The Payer Dal Formation was also sampled at the Sortelv river, south of Steensby Bjerg (Fig. 2, Locality 2). Samples from a third section through the Pelion Formation at Stensiö Plateau (Fig. 2, Locality 3) provide good supplementary material from the lowermost part of the succession, which is poorly represented in the section at Steensby Bjerg. Most of the analysed samples are from finegrained thin beds or lamina in the otherwise coarsegrained, sandy Pelion and Payer Dal Formations. The number of samples and their stratigraphical distribu- 


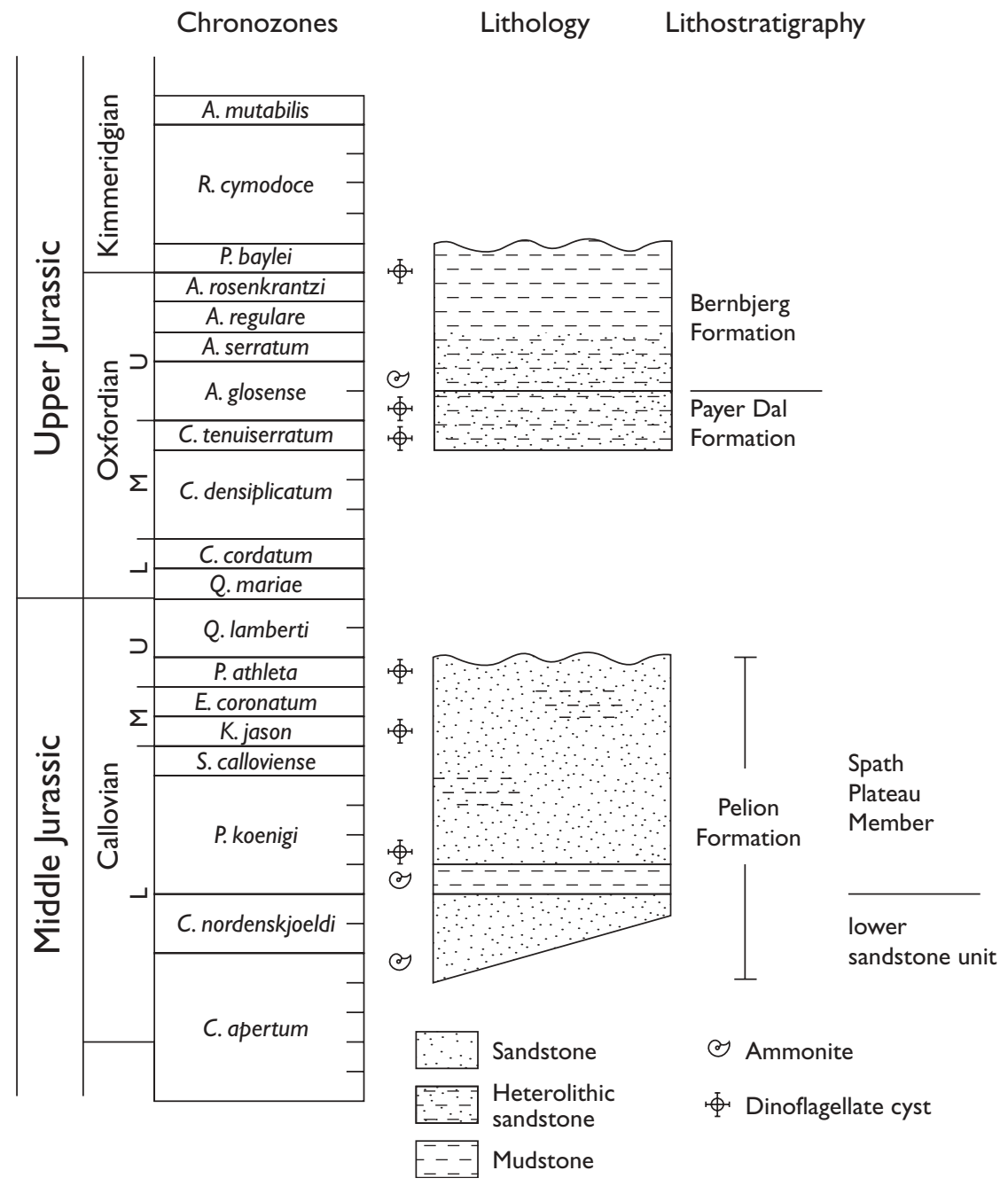

Fig. 3. Schematic correlation of the Jurassic succession on northern Hold with Hope. The lithostratigraphical units are correlated with the Middle to Upper Jurassic chronozonation on the basis of ammonites and dinoflagellate cysts. Points of correlation to chronozones are indicated by ammonite or dinoflagellate cyst signatures. The subdivision of the chronozones corresponds to the ammonite faunas in the biozonation.

tion are controlled by the occurrence and accessibility of these fine-grained beds. In contrast, the shale of the Bernbjerg Formation provides productive samples throughout the formation.

Standard palynological preparation has been performed on most samples. A minority of the samples were prepared by the tank-preparation method (Poulsen et al. 1990). Both methods involve treatment with hydrofluoric (HF) and hydrochloric acids ( $\mathrm{HCl})$ followed by filtering at $20 \mu \mathrm{m}$ mesh size, short oxidation by nitric acid $\left(\mathrm{HNO}_{3}\right)$ and washing in low concentration potassium hydroxide $(\mathrm{KOH})$.

\section{Biostratigraphy}

The ammonites and dinoflagellate cysts have been analysed and correlated to the Boreal ammonite and dinoflagellate stratigraphy, i.e. East Greenland strati- graphy (Callomon 1993; Milner \& Piasecki 1996; Piasecki 1996; Piasecki \& Stemmerik 2004, this volume; Piasecki et al. 2004, this volume).

\section{Ammonites}

Ammonites are very restricted in the Jurassic succession on Hold with Hope, and only three horizons have been dated and correlated with the standard Boreal ammonite stratigraphy (Callomon 1993). A specimen referred to Cadoceras cf. breve (J.H. Callomon and P. Alsen, personal communications 1997) was found $10 \mathrm{~m}$

\section{Facing page:}

Fig. 4. Simplified sedimentological logs of the Jurassic succession from Localities 1, 2 and 3 on northern Hold with Hope. The formal and informal lithostratigraphic units are indicated together with the ammonite horizons; 1.s., lower shale. 


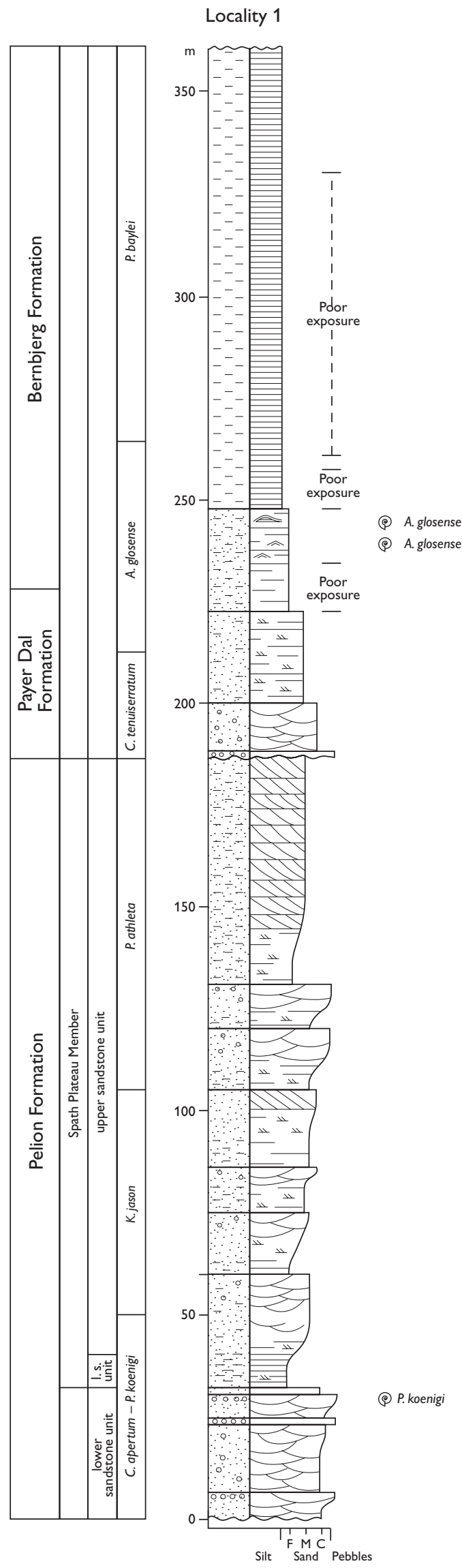

Lithology

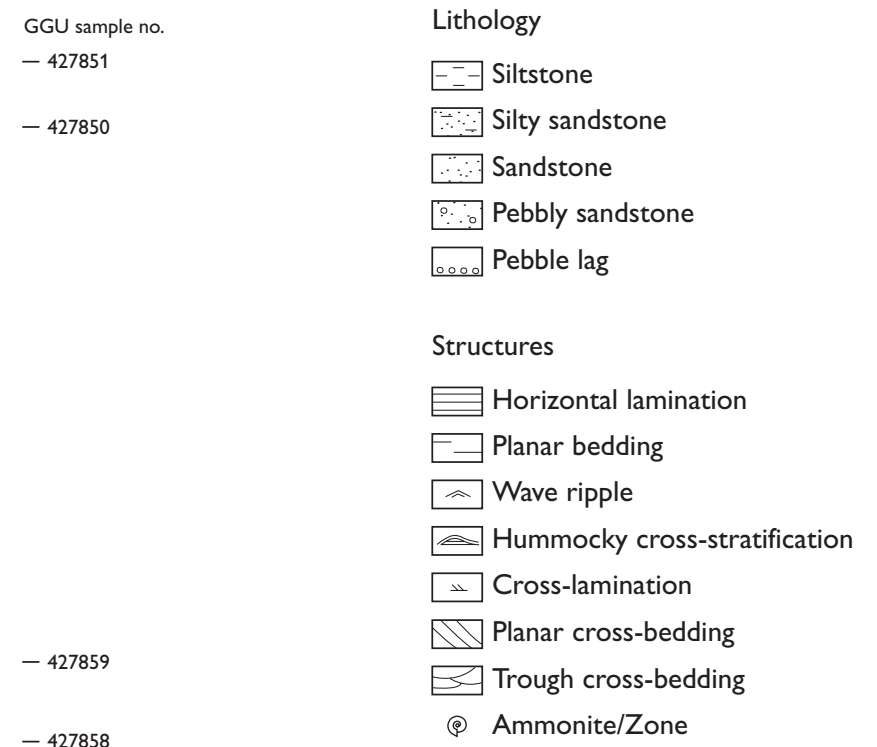

GGU sample no.

$-427858$

( Ammonite/Zone

Structures

E Horizontal lamination

$\exists$ Planar bedding

^ Wave ripple

$\approx$ Hummocky cross-stratification

$\Perp$ Cross-lamination

11 Planar cross-bedding

3 Trough cross-bedding

(9) A. glosense

A. glosense

-427810
-427809

$-427796$

Locality 2

GGU sample no.

$-427793$

$-427790$
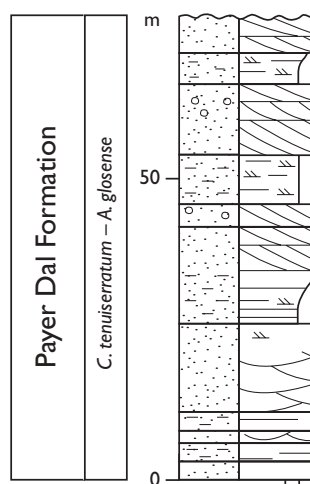

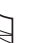

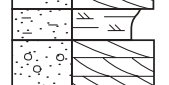

-

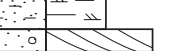

$-427780$

$-427840$

$-427833$

$-427836$

Locality 3

-427730
-427729

$=427818$

$-427705$

427717
427729

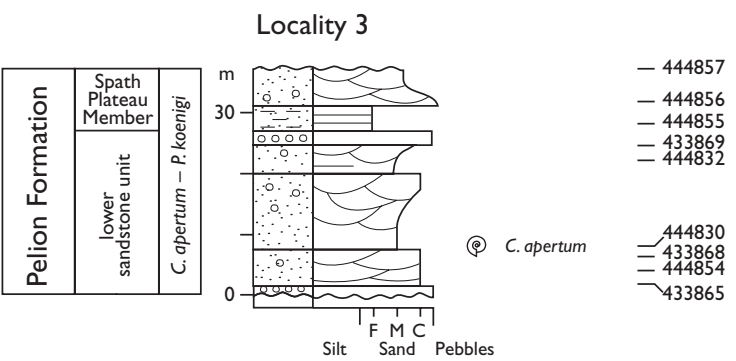


above the base of the lower sandstone unit in the Pelion Formation and indicates the Cadoceras apertum Zone (Fig. 4). A poorly preserved ammonite referred tentatively to Cadoceras septentrionale (P. Alsen, personal communication 1998) in the lowermost Spath Plateau Member of the Pelion Formation indicates the Proplanulites koenigi Zone. Much higher in the succession, in the basal Bernbjerg Formation, the presence of Amoeboceras ilovaiskii (J.H. Callomon and P. Alsen, personal communications 1997) indicates the Amoeboceras glosense Zone.

These three ammonite horizons occur at separate localities (Fig. 4). The C. apertum Zone is identified in the succession at Stensiö Plateau (Locality 3), the $P$. koenigi Zone is identified in the succession at Gulelv (Locality 1 ) and the A. glosense Zone is identified in the section at Sortelv (Locality 2). A calcareous concretion with a specimen of Cranocephalites sp. ( $C$. pompeckji Zone) is reworked into the Cretaceous basal conglomerate. The ammonite data thus indicate that parts of the lower Pelion Formation are equivalent to the C. apertum - P. koenigi Chronozones, Lower Callovian, and parts of the lower Bernbjerg Formation are equivalent to the $A$. glosense Chronozone, Upper Oxfordian. A more detailed stratigraphical framework is provided by the more consistently occurring dinoflagellate cysts.

\section{Dinoflagellate cysts}

The dinoflagellate cyst data are described below in relation to five lithostratigraphic units, as presented by Vosgerau et al. (2004, this volume).

\section{Pelion Formation, lower sandstone unit}

The dinoflagellate cyst assemblages are of low to moderate diversity and density in the samples from this coarse-grained unit. The most diverse assemblages were recovered from the succession at Stensiö Plateau (Figs 2, 4, 5, Locality 3). Many of the species in this assemblage are known from strata in East Greenland older than the Early Callovian age indicated here by ammonites (Milner \& Piasecki 1996). Three assemblages have been distinguished in this unit, based on a limited number of samples. A lower assemblage of poor diversity with frequent Chytroeisphaeridia byalina and Sentusidinium sp. D (Fensome 1979) is followed by a middle assemblage of higher diversity with abundant
Sirmiodinium grossii, Valensiella dictydia and Sentusidinium spp. The third and uppermost assemblage, above the ammonite horizon of the C. apertum Zone, is moderately to highly diverse and contains abundant Chytroeisphaeridia byalina, Rbynchodiniopsis cladophora, R. cf. cladophora and Pareodinia pachyceras (Fig. 5).

The corresponding succession at Steensby Bjerg (Figs 2, 6, Locality 1) contains a very poor dinoflagellate cyst assemblage and Chytroeisphaeridia hyalina is the only frequent species. However, also at this locality slightly more species appear in the uppermost strata of the unit, thus showing an upwards increase in diversity.

Correlation. The succession of species appearances up through the lower sandstone unit of the Pelion Formation in the Stensiö Plateau succession (Locality 3) does not yield any significant stratigraphic information. However, the abundance of Chytroeisphaeridia byalina combined with the earliest appearance of Fromea tornatilis, Pareodinia prolongata, Aldorfia aldorfensis and Kallosphaeridium sp. in this unit are considered indicative of the C.apertum Chronozone based on comparison to the dinoflagellate records in Jameson Land and Store Koldewey (Milner \& Piasecki 1996; Piasecki et al. 2004, this volume). This is also in accordance with the ammonite record in this succession.

The poor dinoflagellate assemblage from the 'lower sandstone unit' at Steensby Bjerg (Locality 1) does not provide clear correlation but contains some characteristic species, e.g. Paraevansia brachythelis which has its lowest record in the $C$. apertum Chronozone on Store Koldewey (Piasecki et al. 2004, this volume).

Several species that are restricted to the upper assemblage of the Stensiö Plateau succession are also limited to the topmost strata of the corresponding unit in the succession at Steensby Bjerg: Aldorfia aldorfensis, Lithodinia planoseptata, Ctenidodinium thulium and Pareodinia prolongata. However, other species from the upper assemblage in the Stensiö Plateau succession (C. apertum Chronozone at Locality 3) appear for the first time at a stratigraphically higher level in the Steensby Bjerg succession (Locality 1). This may reflect the restricted material and data from this unit in the Steensby Bjerg succession (Locality 1).

Age. The age of the 'lower sandstone unit' of the Pelion Formation is Early Callovian, equivalent to the $C$. apertum - P. koenigi Chronozones based on ammonites and dinoflagellate cysts. 
Depositional environment. The presence of a low diverse assemblage with Limbicysta bjaerkei in the basal strata combined with significant, upwards increasing diversity indicate that deposition of this unit began in a marginal marine environment and changed to deposition in a fully marine environment. The preferred habitat of L. bjaerkei is non-marine (Bailey \& Hogg 1995) but it also has been recorded in restricted marine dinoflagellate cyst assemblages, for example in the basal strata of the Payer Dal Formation in Hochstetter Forland (Piasecki \& Stemmerik 2004, this volume). Here, L. bjaerkei occurs together with the marine fauna immediately above non-marine-brackish sediments.

\section{Pelion Formation, Spath Plateau Member, lower shale unit}

The diversity and especially abundance of dinoflagellate cysts reach a maximum in the basal mudstone of the Spath Plateau Member. In the Stensiö Plateau succession (Locality 3), the composition of the assemblage is not significantly different from the highest assemblage in the unit below. However, in the Steensby Bjerg succession (Locality 1), several species appear stratigraphically delayed compared to the Stensiö Plateau succession and their appearance in this 'lower shale unit' produces a local, significant increase in the diversity (Fig. 6). Chytroeispharidia byalina is very abundant at both localities together with frequent Sirmiodinium grossi, Sentusidinium pelionense, Rhynchodiniopsis cladophora, $R$. cf. cladophora and Sentusidinium sp. D (Fensome 1979).

Correlation. The ammonite biostratigraphy shows that the mudstone is within or above the C.apertum and the P. koenigi Chronozones at Localities 1 and 3, respectively. The dinoflagellate biostratigraphy suggests that this mudstone is of the same age at Localities 1 and 3, i.e. equivalent to the P. koenigi Chronozone, but the stratigraphic resolution does not exclude the possibility that the basal mudstone at Locality 3 may include strata from the C. apertum Chronozone. This is the stratigraphical lower limit based on ammonites (Fig. 4). It is possible that the mudstone is diachronous.

The ammonite found in sandstone at the lithostratigraphic transition to the basal mudstone of the Spath Plateau Member at Locality 1 (Fig. 4), is referred to the Proplanulites koenigi Zone. Most of the dinoflagellate species that appear just above the ammonite at this locality, are reported to appear for the first time in or near the C. apertum Chronozone. The highest occurrence of Paragonyaulacysta retiphragmata is found at the same level in both successions (Localities 1, 3) and indicates the P. koenigi Chronozone based on its last occurrence in the Jameson Land Basin (Milner \& Piasecki 1996). The highest occurrence of Kallosphaeridium bypornatum in Jameson Land is also in the $P$. koenigi Chronozone. Pareodinia stegasta appears in the basal mudstone as it does in a stratigraphically comparable transgressive shale unit on Store Koldewey (Piasecki et al. 2004, this volume). The lower boundary of the Spath Plateau Member is a major drowning surface overlain by mudstone both on Hold with Hope and on Store Koldewey (Piacecki et al. 2004, this volume; Vosgerau et al. 2004, this volume).

Age. The age of the 'basal shale unit' of the Spath Plateau Member is Early Callovian, equivalent to the C. apertum - P. koenigi Chronozones.

Depositional environment. The maximum diversity and density of dinoflagellate cysts in the Middle Jurassic succession occur in this unit and indicate deposition of shelf mudstone in a fully marine environment during flooding.

\section{Pelion Formation, Spath Plateau Member, upper sandstone unit}

Samples are available only from the succession at Steensby Bjerg (Locality 1). The dinoflagellate assemblage is moderately rich and diverse. The bulk of the species are the same as in the shale below, but are combined with more species higher in the succession that typically appear in the Callovian. Chytroeisphaeridia byalina, Gonyaulacysta jurassica, Rbynchodiniopsis cladophora and Sentusidinium spp. are most frequent. Mendicodinium groenlandicum appears in the lower part of the unit and Tubotuberella eisenackii and Trichodinium scarburghense appear higher in the unit.

Correlation. The overall Callovian dinoflagellate assemblage provides few stratigraphical markers. The unit is stratigraphically restricted downwards by the presence of Lower Callovian dinoflagellate cysts and ammonites (P. koenigi Chronozone) in the shale unit below. Records from the Jameson Land Basin indicate that Mendicodinium groenlandicum appears in the $K$. 


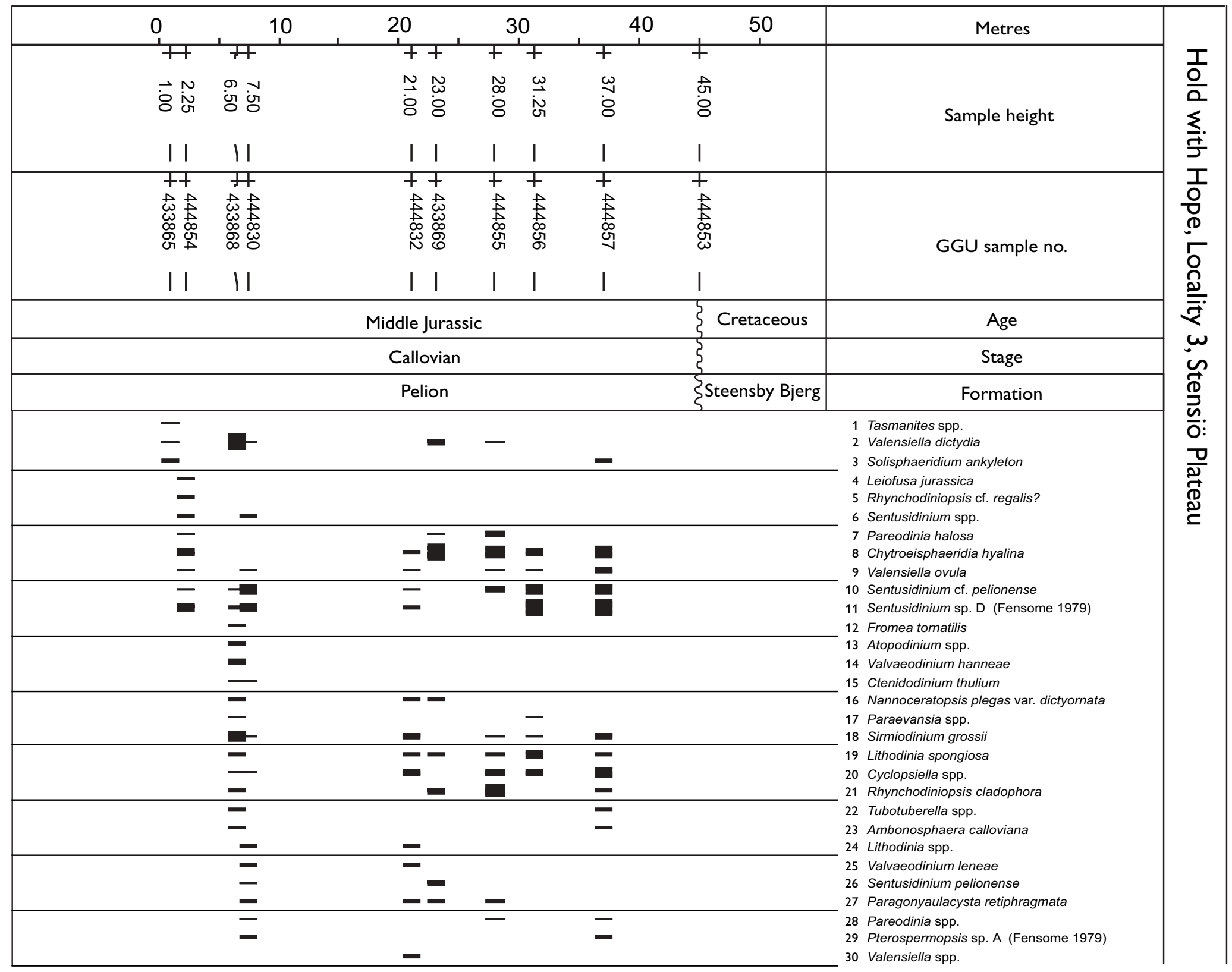




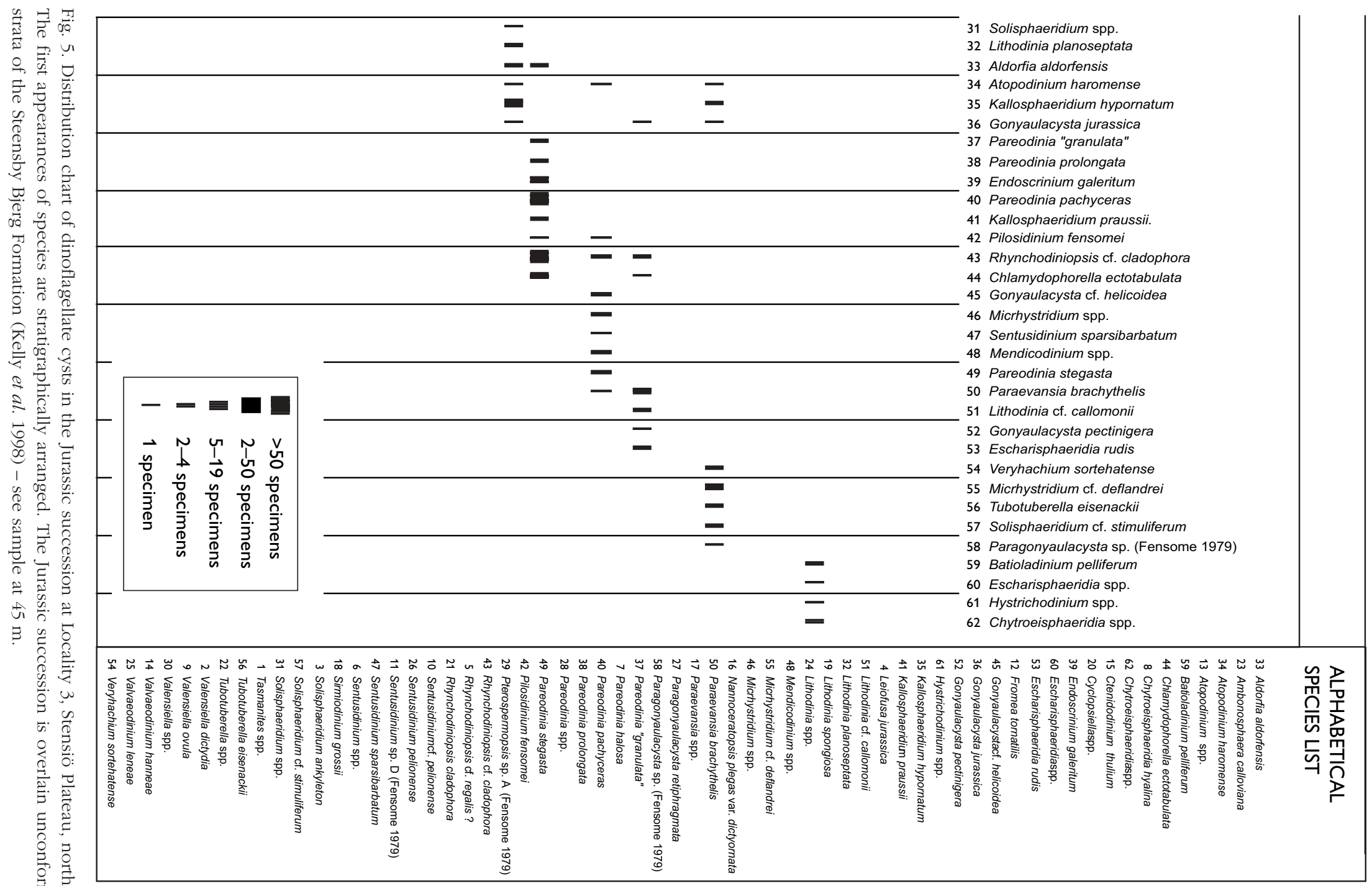




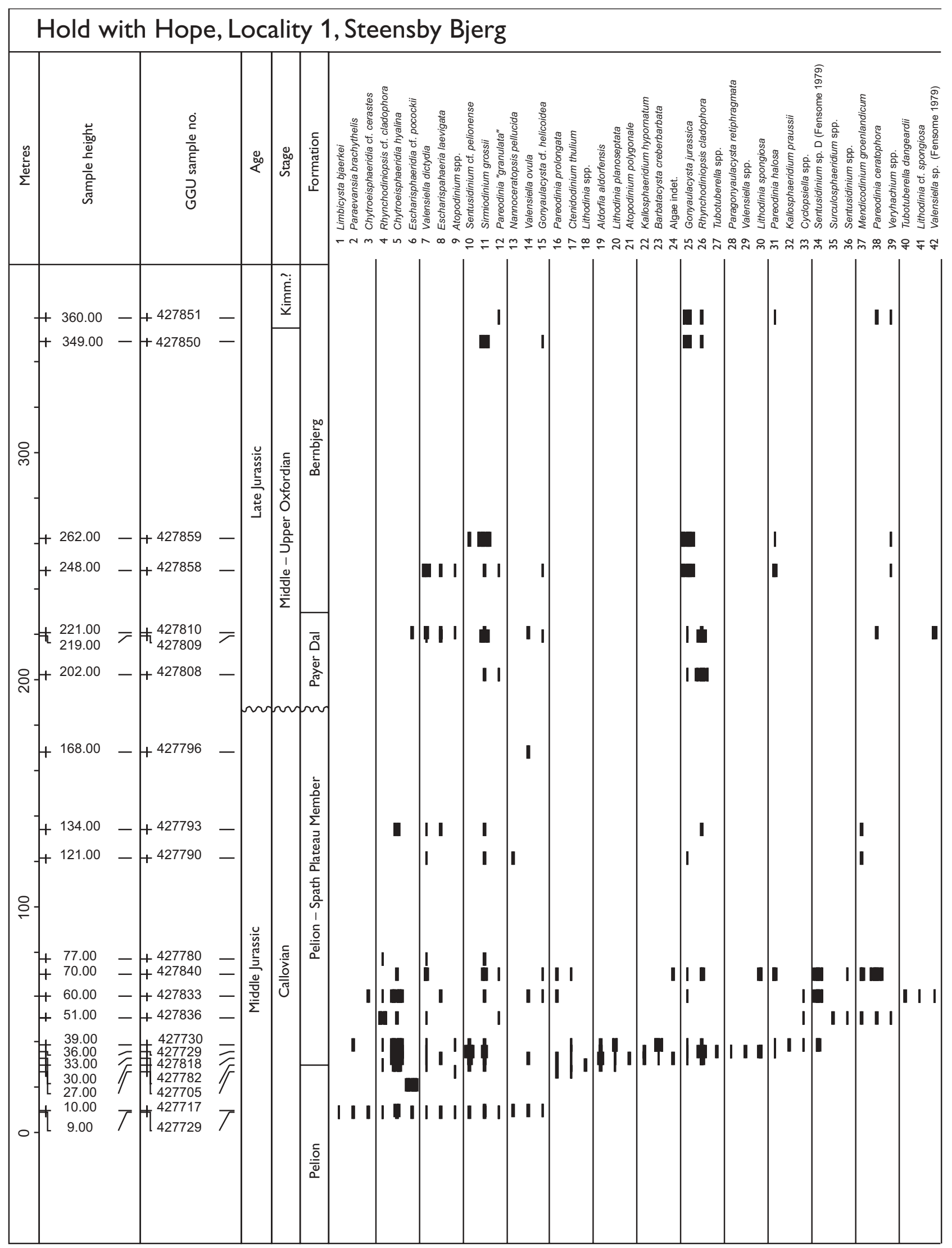




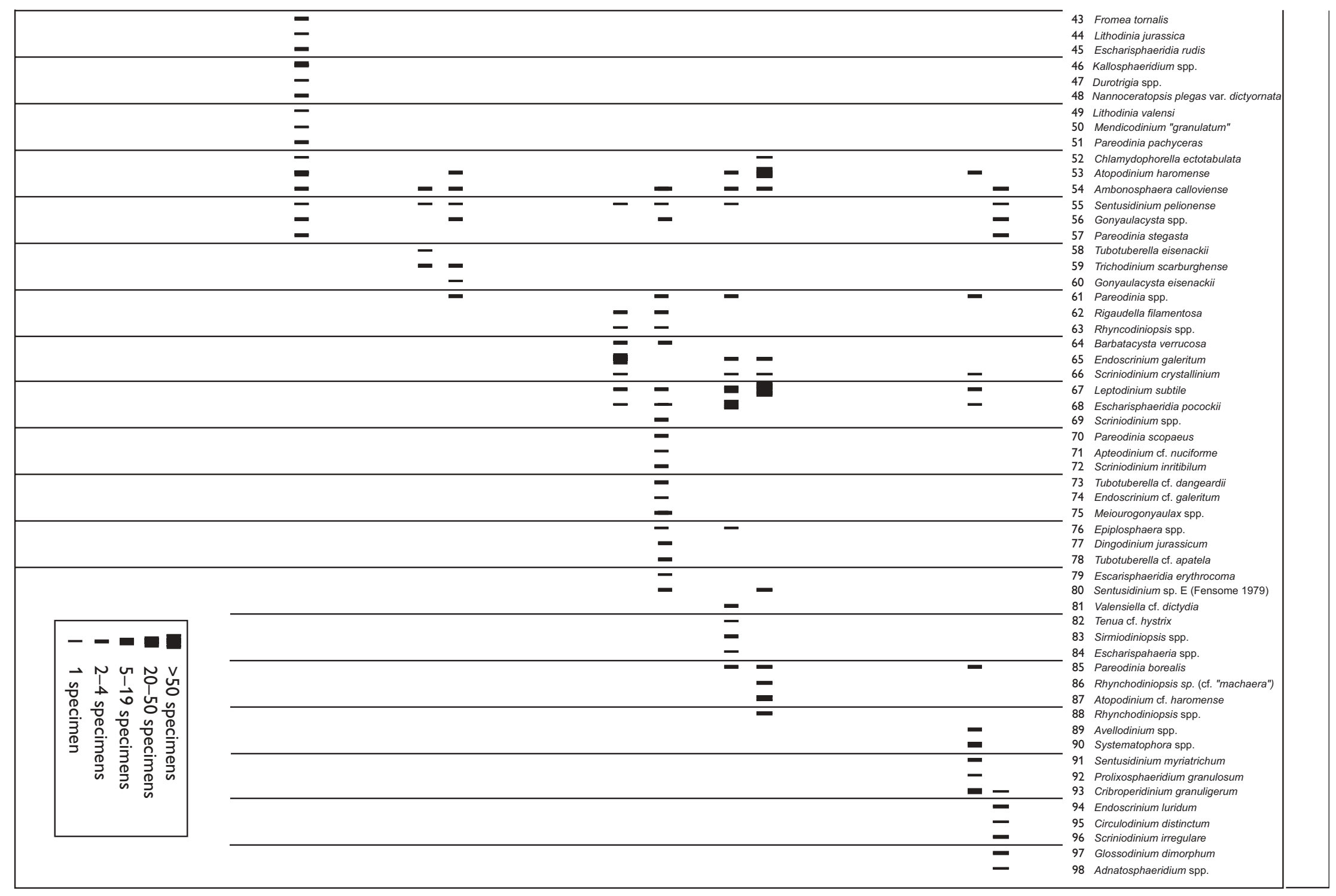


jason Chronozone and Trichodinium scarburghense appears in the P. atbleta Chronozone (Milner \& Piasecki 1996; Piasecki 1996).

Age. The age of the upper sandstone unit of the Spath Plateau Member, Pelion Formation, is therefore Early to Late Callovian, equivalent to the P. koenigi $-P$. athleta Chronozones (Fig. 4).

Depositional environment. The organic matter is dominated by terrestrial palynomorphs and debris. The proportion of brown and black lath-shaped woody material increases upwards until it completely dominates the organic content in the upper Pelion Formation. The upwards increase and dominance of woody material suggests deposition in the lower shoreface environment in front of a prograding shoreline.

\section{Payer Dal Formation}

The Payer Dal Formation was analysed from two localities at Steensby Bjerg, along the Sortelv (Locality 2) and Gulelv (Locality 1) rivers (Figs 2, 4, 6, 7). The formation is characterised by frequent Rigaudella aemula, Rhynchodiniopsis cladophora, Sirmiodinium grossii and Gonyaulacysta jurassica. New, stratigraphically characteristic species appear in the lower part of the formation at Sortelv: Wanaea digitata, Rigaudella aemula and Leptodinium subtile. Higher in the formation at both localities further stratigraphically significant species appear: Scriniodinium crystallinum, Endoscrinium galeritum, Chytroeisphaeridia chytroeides, Rhynchodiniopsis sp., Prolixosphaeridium granulosum and Dingodinium jurassicum.

Correlation. The dinoflagellate assemblage represents a characteristic Lower to Middle Oxfordian assemblage with frequent Rigaudella aemula, Scrinidinium crystallinum and Endoscrinium galeritum, as known from the Jurassic succession elsewhere in East Greenland such as in Milne Land (Piasecki 1996). This LowerMiddle Oxfordian assemblage in Milne Land reaches close to the top of the Middle Oxfordian before gradual replacement by an Upper Oxfordian assemblage. Wanaea spp. occurs only to the top of the Lower

\section{ALPHABETICAL SPECIES LIST}

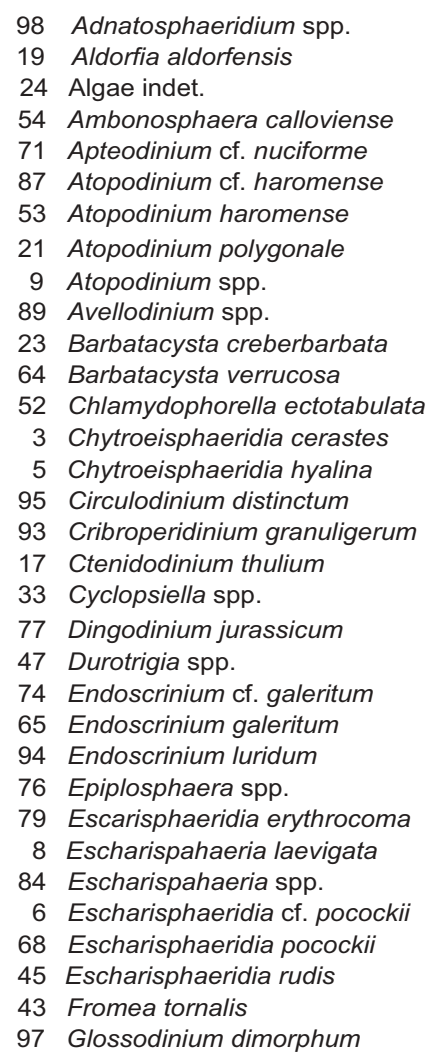

60 Gonyaulacysta eisenackii

15 Gonyaulacysta cf. helicoidea

25 Gonyaulacysta jurassica

56 Gonyaulacysta spp.

22 Kallosphaeridium hypornatum

32 Kallosphaeridium praussii

46 Kallosphaeridium spp.

67 Leptodinium subtile

1 Limbicysta bjaerkei

41 Lithodinia cf. spongiosa

44 Lithodinia jurassica

20 Lithodinia planoseptata

30 Lithodinia spongiosa

18 Lithodinia spp.

49 Lithodinia valensi

75 Meiourogonyaulax spp.

50 Mendicodinium "granulatum"

37 Mendicodinium groenlandicum

48 Nannoceratopsis plegas var. dictyornata

13 Nannoceratopsis pellucida

2 Paraevansia brachythelis

28 Paragonyaulacysta retiphragmata

12 Pareodinia "granulata"

85 Pareodinia borealis

38 Pareodinia ceratophora

31 Pareodinia halosa

51 Pareodinia pachyceras

16 Pareodinia prolongata

70 Pareodinia scopaeus

61 Pareodinia spp.

57 Pareodinia stegasta

92 Prolixosphaeridium granulosum

4 Rhynchodiniopsis cf. cladophora

\author{
86 Rhynchodiniopsis sp. (cf. "machaera") \\ 26 Rhynchodiniopsis cladophora \\ 88 Rhynchodiniopsis spp. \\ 63 Rhynchodiniopsis spp. \\ 62 Rigaudella filamentosa \\ 66 Scriniodinium crystallinium \\ 72 Scriniodinium inritibilum \\ 96 Scriniodinium irregulare \\ 69 Scriniodinium spp. \\ 10 Sentusidinium cf. pelionense \\ 91 Sentusidinium myriatrichum \\ 55 Sentusidinium pelionense \\ 34 Sentusidinium sp. D (Fensome 1979) \\ 80 Sentusidinium sp. E (Fensome 1979) \\ 36 Sentusidinium spp. \\ 83 Sirmiodiniopsis spp. \\ 11 Sirmiodinium grossii \\ 35 Surculosphaeridium spp. \\ 90 Systematophora spp. \\ 82 Tenua cf. hystrix \\ 59 Trichodinium scarburghense \\ 78 Tubotuberella cf. apatela \\ 73 Tubotuberella cf. dangeardii \\ 40 Tubotuberella dangeardii \\ 58 Tubotuberella eisenackii \\ 27 Tubotuberella spp. \\ 81 Valensiella cf. dictydia \\ 7 Valensiella dictydia \\ 14 Valensiella ovula \\ 42 Valensiella sp. (Fensome 1979) \\ 29 Valensiella spp. \\ 39 Veryhachium spp.
}

Previous page:

Fig. 6. Distribution chart of dinoflagellate cysts in the Jurassic succession at Locality 1, Steensby Bjerg, northern Hold with Hope. The first appearances of species are stratigraphically arranged. Alphabetical species list given above. 


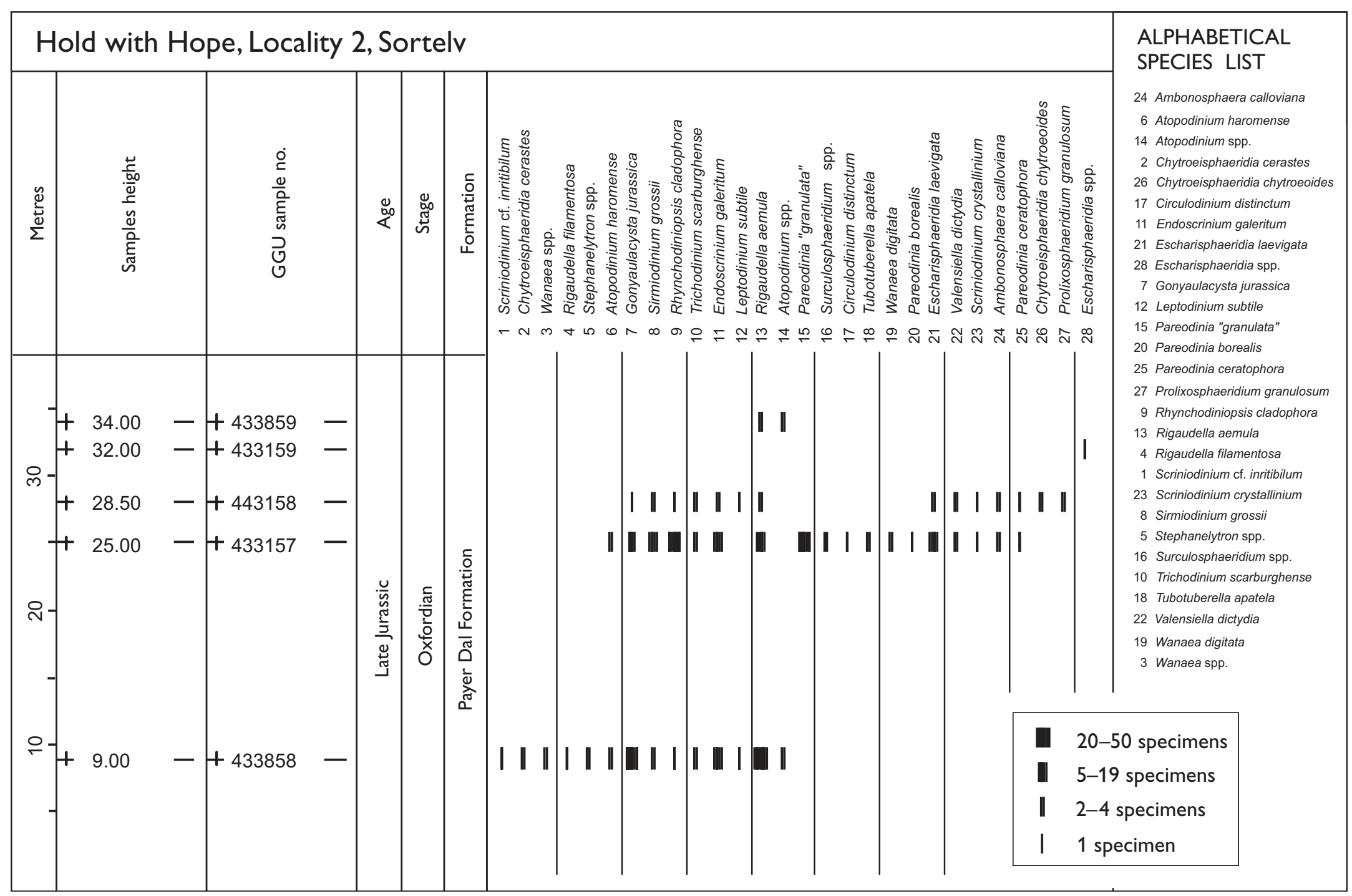

Fig. 7. Distribution chart of dinoflagellate cysts in the Jurassic succession at Locality 2, Sortelv, western Steensby Bjerg, Hold with Hope. The first appearance of species is stratigraphically arranged. 
Oxfordian in Milne Land, whereas Leptodinium subtile rarely occurs below the Middle Oxfordian and Prolixosphaeridium granulosum does not occur below the Upper Oxfordian. The Payer Dal Formation at Locality 1 is therefore considered Middle to Late Oxfordian in age, and the presence of Wanaea digitata, Wanaea sp. and Trichodinium scharburghense in the assemblage is due to reworking. In Milne Land, the appearance of Leptodinium subtile in the $C$. tenuiserratum Chronozone coincides with the gradual disappearance of Rigaudella spp., and the following appearances of Dingodinium jurassicum and Prolixosphaeridium granulosum in the $A$. glosense Chronozone. A corresponding sequence of events in the Steensby Bjerg succession indicates a Middle-Upper Oxfordian succession, C. tenuiserratum-A. glosense Chronozones. Consequently, a significant Late Callovian - earliest Middle Oxfordian hiatus occurs between the Pelion and Payer Dal Formations. However, several samples in the boundary interval (c. $30 \mathrm{~m}$ thick) were barren of dinoflagellate cysts and parts of the succession were therefore not dated. The dinoflagellate cysts, which are considered reworked, indicate that Lower Oxfordian sediments have been present in the region.

Age. The age of the Payer Dal Formation is MiddleLate Oxfordian, equivalent to the C. tenuiserratum A. glosense Chronozones based on dinoflagellate cysts. Ammonites in the overlying Bernbjerg Formation support this age of the uppermost Payer Dal Formation as they indicate the $A$. glosense Chronozone.

Depositional environment. The organic matter is dominated by terrestrial palynomorphs and debris, and the proportion of brown and black lath-shaped woody material is high in the Payer Dal Formation. The organic content suggests deposition in a lower shoreface environment.

\section{Bernbjerg Formation}

The Bernbjerg Formation is represented by a few samples from the lower and upper parts of the formation at Steensby Bjerg (Locality 1). The Bernbjerg Formation contains abundant Sirmiodinium grossii and Gonyaulacysta jurassica. In the lower levels of the formation, the presence of abundant Leptodinium subtile is combined with the appearance of Paragonyaulacysta borealis, Rhynchodiniopsis sp. and Tenua cf. hystrix. The assemblage is very similar to the as- semblage in the upper Payer Dal Formation partly due to the continued presence of Endoscrinium galeritum and Scriniodinium crystallinum. The stratigraphically important Taeniophora sp. / Adnatosphaeridium sp. (informal name 'A. hartzii' in: Piasecki 1980) appears in the uppermost sample from the formation.

Correlation. The continued presence of Endoscrinium galeritum and Scriniodinium crystallinum from the Payer Dal Formation below, and the absence of Taeniophora sp. / Adnathosphaeridium sp. ('A. hart$z i i$ ) correlates with the lower Upper Oxfordian, $A$. glosense Chronozone, by comparison to dinoflagellate floras from Milne Land (Piasecki 1996). This is in accordance with abundant ammonites of the Amoeboceras glosense Zone in these strata, and with the absence of the uppermost Oxfordian dinoflagellate cyst species that appear above.

The upper part of the Bernbjerg Formation contains abundant Gonyaulacysta jurassica and Sirmiodinium grossii in combination with Adnatosphaeridium sp. ('A. hartzii'), Cribroperidinium granuligerum, Sciniodinium irregulare, Glossodinium cf. dimorphum, Endoscrinium luridum and Prolixosphaeridium granulosum. The composite dinoflagellate cyst flora indicates an Upper Oxfordian to lowermost Kimmeridgian succession, A. serratum - P. baylei Chronozones. The presence of Avellodinium spp. in the uppermost sample could indicate the lowermost Kimmeridgian $A$. mutabilis Chronozone, but this is not supported by any other stratigraphical diagnostic species such as Perisseiasphaeridium pannosum (Piasecki 1996; Piasecki \& Stemmerik 2004, this volume).

Age. The age of the Bernbjerg Formation is Late Oxfordian - earliest Kimmeridgian, equivalent to the A. glosense - P. baylei Chronozones based on dinoflagellate cysts. Ammonites in the lower part of the Bernbjerg Formation indicate the $A$. glosense Chronozone and confirm the Late Oxfordian age for this part of the formation.

Depositional environment. The organic content is dominated by terrestrial sporomophs and woody material but dinoflagellate cysts occur frequently. A depositional environment of lower shoreface to open shelf is interpreted on this basis. 


\section{Correlations}

The Pelion Formation on northern Hold with Hope comprises two main units, a lower sandstone unit followed by mudstones and heterolithic sandstones of the Spath Plateau Member. The same overall pattern occurs in the Pelion Formation on Store Koldewey at Ravn Pynt (Piasecki et al. 2004, this volume). However, on Store Koldewey, the lower sandstone unit is older (Bathonian) than the lower sandstone unit on Hold with Hope. The mudstone and overlying sandstone on Store Koldewey are basically of the same Early Callovian age as the lowermost Spath Plateau Member on Hold with Hope (C. apertum - P. koenigi Chronozones). The marine flooding represented by deposition of this mudstone can be traced from Milne Land and Jameson Land in the south (P7 - third order sequence; Engkilde \& Surlyk 2003) to Hold with Hope and Store Koldewey in the north.

The Payer Dal Formation is defined on Kuhn $\varnothing$ where it comprises two units that are of Early-Middle Oxfordian age and early Late Oxfordian age (Alsgaard et al. 2003). On Hold with Hope, the exposure of the oldest part of the Payer Dal Formation at Sortelv (Fig. 2; Locality 2) is limited by a fault, and older strata may be present in the subsurface. However, no strata of Early Oxfordian age have been recorded here, and the age of the Payer Dal Formation on Hold with Hope is Middle-Late Oxfordian, partly corresponding to the upper part of this formation on Kuhn $\varnothing$.

Sedimentation of fine-grained sand and mudstone of the Bernbjerg Formation began in the A. glosense Chron on Hold with Hope as in Wollaston Forland to the north (Surlyk 1977).

\section{Conclusions}

The combined biostratigraphical dataset from ammonites and dinoflagellate cysts dates the stratigraphical range of the lithological units with a high degree of precision (Figs 3, 4). However, the extent of non-depositional or erosional hiati in or between the units cannot be determined with the same certainty due to the limited number of productive samples. The 'basal sandstone unit' of the Pelion Formation ranges from the uppermost $C$. apertum Chronozone to the lower $P$. koenigi Chronozone (Figs 3, 4). The age is therefore Early Callovian. The dinoflagellate assemblages show no indication of a break in sedimentation so the succession is considered complete. The Spath Plateau
Member of the Pelion Formation comprises the P. koenigi, K. jason and P. atbleta Chronozones (Fig. 3). The age is therefore Early to Late Callovian, but a part of the succession occurs above the highest productive sample and may therefore be younger.

A considerable hiatus is present between the Pelion Formation and the overlying Payer Dal Formation. However, the exact stratigraphical position of the unconformity and the extent of the hiatus cannot be determined precisely, because no productive samples were recovered from the boundary interval. The available data suggest a hiatus that comprises most of the Late Callovian, Early Oxfordian and earliest Middle Oxfordian. The Payer Dal Formation ranges from the C. tenuiserratum to the A. glosense Chronozones, and the age is consequently Middle to Late Oxfordian (Fig. 3). The dinoflagellate assemblages indicate no break in deposition at the boundary to the Bernbjerg Formation, and the A. glosense Chronozone is also identified in the basal Bernbjerg Formation on the basis of ammonites. The Jurassic succession and the Bernbjerg Formation are limited upwards by pre-Barremian, Cretaceous erosion, and the highest samples are referred to the $A$. rosenkrantzi - P. baylei Chronozones at the Oxfordian-Kimmeridgian boundary (Fig. 3). The age of the Bernbjerg Formation is thus Late Oxfordian, possibly earliest Kimmeridgian.

The Jurassic succession on northern Hold with Hope correlates well with the corresponding Jurassic successions towards the north and the south, but appears more fragmented compared to these successions. A Boreal Bathonian (Bajocian-Bathonian) succession has been deposited in this region, at least partly, but was removed by later erosion as indicated by the reworked ammonite of the $P$. pompeckji Zone. The previous presence of a Lower Oxfordian succession is similarly indicated by reworked dinoflagellate cysts. The magnitude of the hiatus below the Payer Dal Formation is Late Callovian - Middle Oxfordian.

\section{Acknowledgements}

The present biostratigraphic study was supported by the Carlsberg Foundation (Carlsbergfondet Ans. 980089/ 20-262). John H. Callomon and Peter Alsen are thanked for identification of ammonites from Hold with Hope. The authors are grateful to Jan Jansonius and Susanne Feist-Burkhardt for useful and constructive review comments. 


\section{References}

Alsgaard, P.C., Felt, V.L., Vosgerau, H. \& Surlyk, F. 2003: The Jurassic of Kuhn $\varnothing$, North-East Greenland. In: Ineson, J.R. \& Surlyk, F. (eds): The Jurassic of Denmark and Greenland. Geological Survey of Denmark and Greenland Bulletin 1, 865-892.

Bailey, D. \& Hogg, N.M. 1995: Fentonia bjaerkei gen. et comb. nov.; transfer from Parvocysta Bjaerke 1980. Journal of Micropalaeontology 14(1), $58 \mathrm{pp}$.

Callomon, J.H. 1993: The ammonite succession in the Middle Jurassic of East Greenland. Bulletin of the Geological Society of Denmark 40, 83-113.

Donovan, D.T. 1957: The Jurassic and Cretaceous systems in East Greenland. Meddelelser om Grønland 155(4), 1-214.

Engkilde, M. \& Surlyk, F. 2003: Shallow marine syn-rift sedimentation: Middle Jurassic Pelion Formation, Jameson Land, East Greenland. In: Ineson, J.R. \& Surlyk, F. (eds): The Jurassic of Denmark and Greenland. Geological Survey of Denmark and Greenland Bulletin 1, 813-863.

Fensome, R.A. 1979: Dinoflagellate cysts and acritarchs from the Middle and Upper Jurassic of Jameson Land, East Greenland. Bulletin Grønlands Geologiske Undersøgelse 132, 98 pp.

Kelly, S.R.A., Whitham, A.G., Koraini, A.M. \& Price, S.P. 1998: Lithostratigraphy of the Cretaceous (Barremian-Santonian) Hold with Hope Group, NE Greenland. Journal of the Geological Society (London) 155(6), 993-1008.

Larsen, M., Piasecki, S., Preuss, T., Seidler, L., Stemmerik, L., Therkelsen, J. \& Vosgerau, H. 1997: Petroleum geological activities in East Greenland in 1997. Geology of Greenland Survey Bulletin 180, 35-42.

Milner, P.S. \& Piasecki, S. 1996: Boreal Middle Jurassic dinoflagellate cyst stratigraphy of Jameson Land, East Greenland. In: Piasecki, S. et al. (eds): Formation of source and reservoir rocks in a sequence stratigraphic framework, Jameson Land, East Greenland. Energy research programme EFP-93, projects 1313/93-0010 and 0017. Danmarks og Grønlands Geologiske Undersøgelse Rapport 1996/30, Vol. I \& II, 46 pp.

Piasecki, S. 1980: Middle to Late Jurassic dinoflagellate cyst stratigraphy from Milne Land and Jameson Land (East Greenland) correlated with ammonite stratigraphy, $167 \mathrm{pp}$. Unpublished Ph.D. thesis, University of Copenhagen, Denmark.

Piasecki, S. 1996: Boreal dinoflagellate cyst stratigraphy of Middle to Upper Jurassic sediments of Milne Land, East Greenland. In: Piasecki, S. et al. (eds): Formation of source and reservoir rocks in a sequence stratigraphic framework, Jameson Land, East Greenland. Energy Research Programme EFP-
93, projects 1313/93-0010 and 0017. Danmarks og Grønlands Geologiske Undersøgelse Rapport 1996/30, Vol. I \& II, 100 pp.

Piasecki, S. \& Stemmerik, L. 2004: Jurassic dinoflagellate cysts from Hochstetter Forland, North-East Greenland. In: Stemmerik, L. \& Stouge, S. (eds): The Jurassic of North-East Greenland. Geological Survey of Denmark and Greenland Bulletin 5, 89-97 (this volume).

Piasecki, S., Callomon, J.H. \& Stemmerik, L. 2004: Jurassic dinoflagellate cyst stratigraphy of Store Koldewey, North-East Greenland. In: Stemmerik, L. \& Stouge, S. (eds): The Jurassic of North-East Greenland. Geological Survey of Denmark and Greenland Bulletin 5, 99-112 (this volume).

Poulsen, N.E., Gudmundsson, L., Hansen, J.M. \& Husfelt, Y. 1990: Palynological preparation techniques, a new Macerationtank-method and other modifications. Danmarks Geologiske Undersøgelse Serie C 10, 22 pp.

Price, S.P. \& Whitham, A.G. 1997: Exhumed hydrocarbon traps in East Greenland: analogs for the Lower-Middle Jurassic play of Northwest Europe. American Association of Petroleum Geologists Bulletin 81, 196-221.

Stemmerik, L., Clausen, O.R., Korstgård, J., Larsen, M., Piasecki, S., Seidler, L., Surlyk, F. \& Therkelsen, J. 1997: Petroleum geological investigations in East Greenland: project 'Resources of the sedimentary basins of North and East Greenland'. Geology of Greenland Survey Bulletin 176, 29-38.

Surlyk, F. 1977: Stratigraphy, tectonics and palaeogeography of the Jurassic sediments of the areas north of Kong Oscars Fjord, East Greenland. Bulletin Grønlands Geologiske Undersøgelse 123, 56 pp.

Surlyk, F. 1978: Mesozoic geology and palaeogeography of Hochstetter Forland, East Greenland. Bulletin of the Geological Society of Denmark 27, 73-87.

Surlyk, F., Clemmensen, L.B. \& Larsen, H.C. 1981: Post-Palaeozoic evolution of the East Greenland continental margin. In: Kerr, J.W. \& Fergusson, A.J. (eds): Geology of the North Atlantic borderlands. Canadian Society of Petroleum Geologists Memoir 7, 611-645.

Vischer, A. 1943: Die postdevonische Tektonik von Ostgrönland zwischen $74^{\circ}$ und $75^{\circ} \mathrm{N}$. Br. Kuhn $\varnothing$, Wollaston Forland, Clavering $\varnothing$ und angrenzende Gebiete. Meddelelser om Grønland 133(1), 195 pp.

Vosgerau, H., Larsen, M., Piasecki, S. \& Therkelsen, J. 2004: A new Middle-Upper Jurassic succession on Hold with Hope, North-East Greenland. In: Stemmerik, L. \& Stouge, S. (eds): The Jurassic of North-East Greenland. Geological Survey of Denmark and Greenland Bulletin 5, 51-71 (this volume). 